\title{
COLLABORATIVE CARE IN HEALTH INSTITUTIONS: THE NURSE AS INTEGRATOR
}

\author{
Vera Regina Waldow ${ }^{1}$
}

\footnotetext{
${ }^{1}$ Ph.D. in Education. Retired professor of the School of Nursing of the Universidade Federal do Rio Grande do Sul. Porto Alegre, Rio Grande do Sul, Brazil. E-mail: waldowvr@portoweb.com.br
}

\begin{abstract}
This theoretical study aimed to share and propose a vision regarding collaborative work in the area of health, in the perspective of care. The nurse is considered the leader in this process, responsible for spreading and motivating principles of care among the nursing team and the other health professionals; the goal is collaborative work impacting positively on the relationships between the various professionals, patients and family members, resulting in an atmosphere where behaviors of care, such as solidarity, cooperation and respect, may be shown, contributing to competent and sensitive care.
\end{abstract}

DESCRIPTORS: Nursing. Nursing care. Work environment. Cooperative behavior.

\section{CUIDADO COLABORATIVO EM INSTITUIÇÕES DE SAÚDE: A ENFERMEIRA COMO INTEGRADORA}

RESUMO: Estudo teórico que teve como objetivo compartilhar e propor uma visão sobre trabalho colaborativo na área da saúde, na perspectiva do cuidado. A(o) enfermeira(o) é considerada a líder neste processo, responsável por difundir e motivar princípios de cuidado entre a equipe de enfermagem e demais profissionais da saúde; a meta é um trabalho de colaboração que repercuta positivamente nas relações entre os diversos profissionais, pacientes e familiares, resultando em um ambiente onde comportamentos de cuidado, tais como solidariedade, cooperação e respeito sejam exibidos de forma a contribuir para um cuidado competente e sensível.

DESCRITORES: Enfermagem. Cuidado de enfermagem. Ambiente de trabalho. Comportamento cooperativo.

\section{CUIDADO COLABORATIVO EN INSTITUCIONES DE SALUD: LA ENFERMERA(O) COMO INTEGRADOR(A)}

RESUMEN: estudio teórico que tuvo como objetivo compartir y proponer una visión sobre trabajo colaborativo en el área de salud bajo la perspectiva del cuidado. $\mathrm{La}(\mathrm{el})$ enfermera(o) es considerada la líder en este proceso, responsable por difundir y motivar principios de cuidado entre el equipo de enfermería y demás profesionales de la salud. La meta es un trabajo colaborativo que repercuta positivamente en las relaciones entre los diversos profesionales, pacientes y familiares, resultando en un ambiente donde comportamientos, tales como solidaridad, cooperación y respeto sean exhibidos de forma a contribuir para un cuidado competente y sensible.

DESCRIPTORES: Enfermería. Atención en enfermería. Ambiente de trabajo. Conducta cooperativa. 


\section{INTRODUCTION}

The environment is an element of great importance for the development of the process of care in nursing practice. Actually, the environment - or, as some prefer, the atmosphere or surroundings - is of extreme relevance in any institution, whether it is related to family, work, social matters or others. After this point, it is the health sector that is of interest, therefore I shall privilege this environment, principally considering that the same shelters a series of professionals, workers, patients, their family members, relatives and others. The environment will be discussed, in a parallel form, or as a consequence of the relationships which occur in the same between the subjects, as I start from one principle: it is we who create the environment. The relationships were highlighted in another work, ${ }^{1}$ such as those which occur between the professionals, such as between those of medicine and nursing, nursing and administration, the nurse and team and the caregiver and the person cared for.

For these three elements to occur - the relationships of care, the environment of care and collaborative work - it is the nurse, supposed to be the leader of the health team, who should be the pivotal subject, although in reality the nurse exercises leadership only among her peers. Her training, however, like her transit between the various departments of a health institution, and her frequent presence among the patients and their families, favors that she should be the integrating professional. The responsibility attributed to this professional is in the sense of qualification that, in my opinion, is in a privileged position, as nursing has been one of the areas which has a significant amount of literature on the issue of caring/care, as well as being an issue suggested by its professional association - the Brazilian Nursing Association (ABEn), as a result of which various curriculums emphasize this approach in Brazilian schools of nursing. It is in this way that I shall address, in this text, the above-mentioned elements, focusing on the caregiver - nurse - whose objective, in my view, is the care for the patient and her family, as well as among the subjects who pass through the institution.

The present theoretical study aimed to share our vision regarding collaborative work in the area of health, in the perspective of caring. I propose that it should be motivated by the nurse, considering her as the integrating professional in this enterprise. The rationale for the choice of the theme is owed to the fact of considering the care, as considered in this text, to be, on its own, an integrating element whose principal communicator is the nurse, such that all the members of the institution should be sensitized to take responsibility for it in their daily practice. As a consequence, I think that all will benefit, whether professionals, other workers, patients or family members.

\section{CARING RELATIONS AND CARING ENVIRONMENT}

It seems that there is no doubt about one of the characteristics of the caring being a relational activity, as well as a further two important ones which I consider: the existential and contextual dimensions. ${ }^{1-3}$ Care only occurs in relation to another being, that is, another subject, or the care for oneself, constituting what I term as subject-subject care; or, further, in relation to things or objects. Thus, care is interactive, even when words are not exchanged. It is a form of interaction involving dedication, interest, involvement and responsibility. Among subjects, the care can be demonstrated through gestures, postures, looks and touch; as can lack of care.

Some situations - considered situations of non-care - related to the environment in hospital institutions, are described in works. ${ }^{1,4-5}$ They indicate, among others, indifference, negligence, and lack of responsibility and respect on the part of nursing and medical professionals for the patients. The devalorization of the care on the part of health professionals and management impact brutally on motivation and willingness to care, as well as on the willingness and collaboration regarding receiving the care. Patients tend to be treated as objects, and the care actions become obligatory, mechanized, impersonal tasks - sometimes resulting in mistreatment. As a result, patients mention feeling depersonalized, poorly treated and discouraged, as well as expressing anxiety, insecurity and solitude. Patients and family members notice when the professionals show indifference, bad temperedness and lack of sensitivity. On the other hand, when patients noticed that the professionals are attentive, warm, sensitive and interested, they develop feelings of trust, comfort, security and motivation for recovery and relaxation.

Various factors, sometimes, stop the care actions from being undertaken satisfactorily, with kindness, attention and consideration, provoking intolerance and bad-temperedness on the part of 
the team, such as, for example, lack of material or staff, entailing work overload, lack of managerial support, and a lack of team spirit. However, these factors should not result in disrespect and lack of attention.

The components of the organizational culture in healthcare have a significant role in contributing in the provision of resources and support for an embracing environment for all the institution's departments, whose subjects working in these places may all become responsible for the maintenance of this environment.

The organization's components which make up the environment include the physical environment, the managerial environment, the social environment and the technological environment. ${ }^{2-3}$ However, it is within nursing itself that the care is administered and asserted, or as it ideally should be, in its integrity, covering behaviors and attitudes on the part of and among all the subjects involved, such as: responsibility, competence, knowledge, manual and social skills, sensitivity and involvement.

One study addressing the implications of the environment for the development of the nursing team's work process identified, through an integrative review, that some working conditions negatively influence both the nursing work process and the nurse's health. This review emphasized that the caregiver does not know how to care for the client-colleagues or herself. ${ }^{6}$

The nurse, as leader of the team, is the most trained professional for awakening the willingness for comprehensive, sensitive and competent care. The care must be motivated, and awareness about it must be raised, by the leader who, in her turn, must act as a being of care with her team such that the same (the care) may be absorbed and reflected into the environment. Moreover, in this regard, she establishes care relationships, defined as: "those which are distinguished by the expression of behaviors of care, which people share, such as trust, respect, consideration, interest and attention, among others" ${ }^{\prime 1: 133}$ Considering this definition, as people express these behaviors of care as mentioned, an environment of care where these values are highly-valued is automatically created.

An environment of care is defined as that in which "people feel well, recognized and accepted as they are; in which they are able to express themselves authentically and concern themselves with each other in relation to providing and updating information, exchanging ideas, offering help and support and taking responsibility for, and committing themselves to the maintenance of this climate of care" ${ }^{1: 133-134}$ The relationships of care may be of the personal (or private) type, in which a subject-self relationship (caring for oneself) or subject-other relationship occurs. This last generally occurs with members of the family, relatives or friends - and are closer relationships.

The relationships of the social (or public) type are those which are characterized as being subject-other relationships. They occur in this way; however, non-respectful relationships can occur between the subjects, taking on the character of a subject-object relationship. The social relationships include those in which there are no affective bonds, but in which respect, consideration and solidarity, in general, are present, with the exception of the type referred to as subject-object.

In the professional relationships, it is common for the subject-object relationship to occur, this being characterized by the absence of care. In health institutions, this type of relationship is not uncommon, although there is currently a movement in favor of the humanization of the care, in which it is suggested that the relationships should be of respect and consideration, genuinely configuring relationships of care, that is, subject-subject, or in this case, subject-other. Finally, there are relationships which are characterized as being of the subject-this or subject-thing. These can be found in the relationships of care with things and objects, ideas, books, which in general are dear to us, which we hold dear.

The environment in the relationships of care in an organization with a health culture, in this case, that of the hospital, are represented graphically. The figure, and its description, are not at all intended to function as a model; there is, therefore, no intention that it should be prescriptive. ${ }^{2-3}$ It is appropriate to record that both resulted from studies which privileged opinions of subjects who experience situations of caring and being cared for, and aimed to contribute to the teaching of nursing, emphasizing the elements considered important for the process of care to evolve satisfactorily. On the other hand, it attempts to establish a relationship and to contribute with some principles involving reflexive practice.

The reflexive process $^{7}$ and the reflexive practical teaching, ${ }^{8-9}$ it is appropriate to quickly explain, propose, respectively, to reflect upon the assistential practice of nursing and on the reflexive practice in teaching in order to transform the 
practice and develop skills in the students which allow them to think about what they do while they are doing it, contributing to the construction of competences.

These principles can be applied to nursing, at the time of providing caring, in the phases in which reflection supposedly occurs on the part of the protagonists, that is, the reflection-in-the-action and reflection-on-the-action. ${ }^{10}$ The desirable, when the circumstances occur, characterizing care relationships in an environment of care, is that both the subjects - the being who cares and the being who is cared for - should grow and be transformed; promoting and contributing such that the experience of being hospitalized, a patient, and/or dependent should be alleviated and that the ill subject should be enriched, maintaining her dignity, self-esteem and the development of trust, calmness, and faith in herself and in the team, with courage for facing adversity. Caregivers benefit in this process in generating greater knowledge, experience, self-esteem, and feelings of gratification, the duty having been done, realization and satisfaction.

The process of care is defined as constituting "all the activities undertaken by the caregiver for and with the being cared for, based in scientific knowledge, skills, intuition, critical thinking and creativity, accompanied by behaviors and attitudes of care aimed at promoting, maintaining and/or recovering their human dignity and totality". 2:113 The dignity and totality encompass the feeling of integrity and seek to achieve physical, mental, moral, emotional, social and spiritual completeness, in the phases of living and dying, ultimately constituting a process of transformation of both caregiver and the being cared-for. This definition has been slightly modified, in comparison with that published in other works. ${ }^{2}$

\section{O L L A B O R A T I V E C A R E : RESPONSIBILITY OF THE NURSE}

The relationships of care and the environment of care and health institutions contribute - or, rather, respond to - the development of collaborative work. Actually, collaborative work only becomes viable through an approach of care and its practice. The care transforms environments, harmonizes relationships and sensitizes the humane in each subject. ${ }^{2}$

The patient constitutes the focus of the care, and all the actions and activities are for his ben- efit and his family's. However, in talking about collaborative work, I suggest placing the nurse at the epicenter of this process, that is, he or she orchestrates this work, as shall be seen in the figure below. This professional is most prepared, in my view, although the collaborative work must receive cooperation from all those involved; it is the responsibility of all.

The nurse coordinates the therapeutic activities for the patients, which are to be carried out by the nursing team, the procedures, and the actions of care.

Under the characteristics of the current health systems, the nurse is a manager, regardless of level (general coordination, supervision, or management of the unit). Nurses of a unit, as team leaders, perform activities which fall to them by law, which does not stop them from participating in some activities with other caregivers of the team, such as, for example, helping bathe, move or position patients; on the contrary, this participative attitude allows them to know and check the patients' conditions, as well as checking the work of the team. Furthermore, it allows them to be closer to the patients and their work partners, evidencing an attitude which is consistent with a caring approach.

Activities may be considered quality, and achieve their maximum, when all contribute to the climates of trust, respect, unity and a feeling of belonging to the group, making the work more pleasurable.

The family may also be cared for and encouraged to participate in the activities, contributing to the care, and sharing its knowledge about the patient. Being close, being present, and offering help and support favors the patient's cooperation and ensures his identity and trust. Family members also become more secure and self-confident due to feeling useful and grateful for the possibility of sharing the experience and being able to stay with their loved one. The team must recognize and help such that the family can collaborate and become a partner and an agent of care, and such that it feels considered, calmer and comforted.

All must collaborate in the care. Due to the high technology in the hospital institutions, the challenges are more numerous and complex, and individually more difficult to overcome: such that the people, together, as a team, can help each other, strengthen each other, and exchange experiences and knowledges, contributing to a 
work of excellence. The organization benefits from the satisfaction of everybody, as do patients and family members. The quality of the care provides greater credibility with, and recognition from, the community, which will tend to seek its services.

It is important that responsibilities should be shared and that the roles should be explained and defined between the various teams. Care, emphasizing this point one more time, must be sensitized, defined such that the subjects in the organization must have received explanations and have been motivated to collaborate so as to achieve it.
Below is the schematic figure which I devised for collaborative care, in which the greatest responsibility is centered on the figure of the nurse. This professional, as a being of care, that is, a person who is competent and sensitive to exercise her leadership justly and comprehensively, valorizing and motivating her team, recognizing and fighting for their rights, expects, however, each one in the team to meet their obligations and to participate, so as to provide quality care, promoting and maintaining a climate of care. She is generous, but at the same time, is firm.

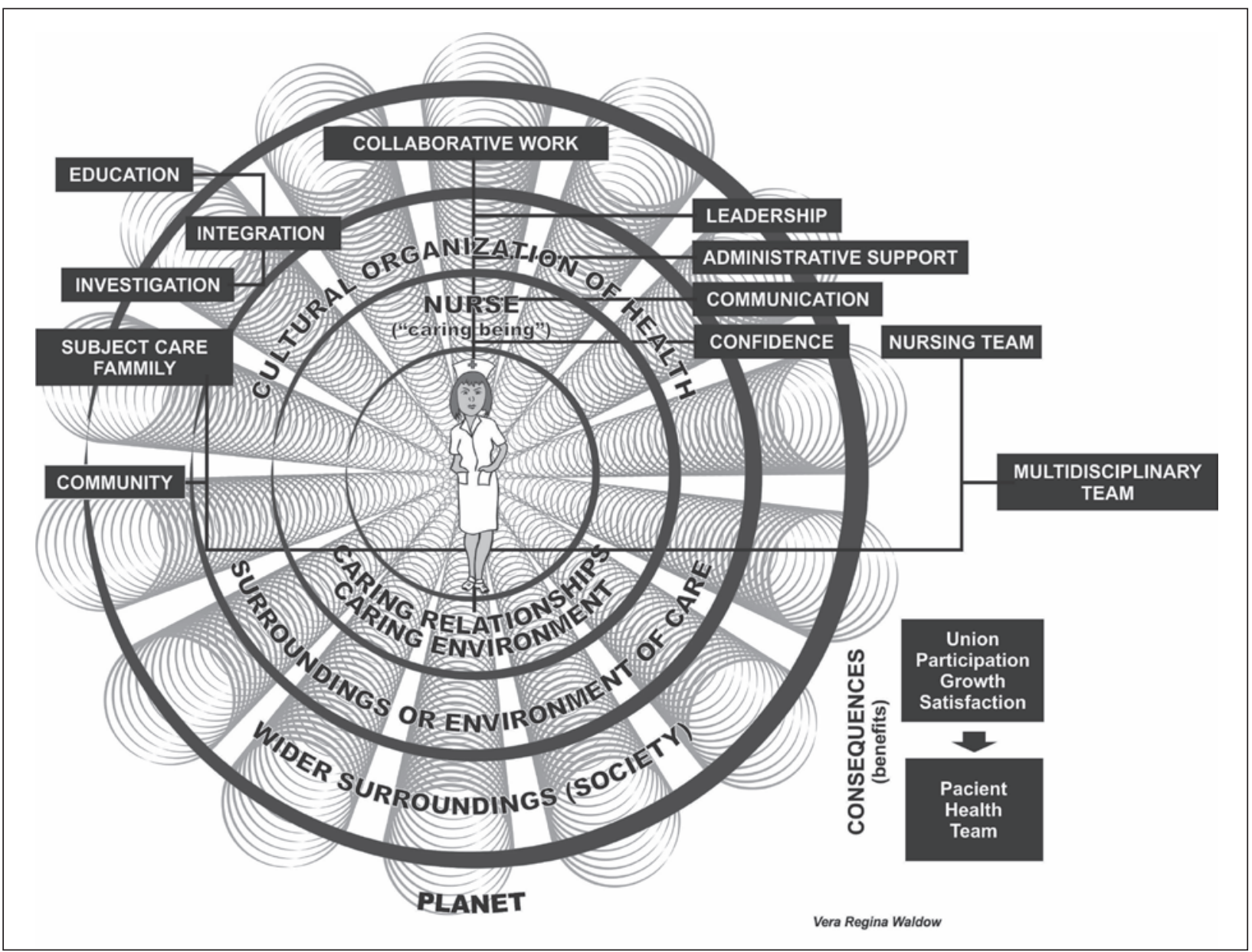

Figure 1 - Graphic representation of collaborative care - the nurse as integrator

\section{COMPONENTS FOR COLLABORATIVE CARE}

The care relationships extend to the patients and their family members, who constitute the main focus, and for whom the care is destined. The multi-professional team also benefits from an environment of care, for which efforts will be made so as to share and contribute to the relationships of care and the maintenance of this climate of care.

The elements of collaborative care in instances of work in health institutions, in which the nurse holds responsibility as integrator encompass: leadership, managerial support, communication, trust and integration. 
Leadership, preferentially as suggested in innovative management, encompasses respect and honesty, allowing conditions for the growth of the team members. These behaviors characterize a committed leadership, which, besides the promotion of growth, motivating the improvement of the subjects who are led, seeks to encourage team spirit and that the subjects feel secure and confident, creating an environment in which it is pleasurable to work, as well as creating affirmative habits and behaviors. A good leader knows how to listen, is a caregiver, and acts as a mobilizer and as a facilitator of the team members' strengths.

It is essential to obtain the support of the institution's management, and that the other managers should be made aware and motivated to create an atmosphere which is favorable to cooperation, in the planning and coordination of activities for each discipline, aiming to achieve the common goals established for collaborative work in a harmonious environment. Each one's efforts are recognized.

The satisfaction of the workers in an institution is in parallel with the recognition and commitment of the management in favor of the well-being of all the subjects to be cared for, not just the patients and their family members, but professionals, technicians and the other components. The managerial support, whether this is the central management or line managers, has as a consequence, besides satisfaction, greater trust for carrying out rhythmical and harmonious teamwork, resulting in greater productivity.

Communication, another fundamental element of the success of collaborative work, actually constitutes a factor of great importance for the leader. The leader must possess the ability to communicate, maintaining good relationships between herself and the nursing team, as well as with the multi-professional team. As leader and a person interested in the development of nursing and of collaborative work, it is important to make clear what nursing does, what its responsibilities are, and what it is responsible for under the law of professional practice, what philosophy it adopts, as well as having to know the responsibilities of each discipline of the multi-professional group, such that all can know how, and on whom to rely, in terms of knowledge and skills. I emphasize the maintenance of a positive channel of communication, obtaining the support of the management, principally ensuring that the policy of humanization should not only be a theoretical discourse, but that it should be able to mobilize all the organization's subjects, in all their sectors and departments.

As indicated above, the facts mentioned, such as positive leadership, managerial support and clear communication, result in confidence on the part of the different teams and other workers. On the other hand, the sensitive humane nurse, with skills in communicating clearly, demonstrating competence, ensures greater integration and confidence, not only from the teams, but also from the patients and family members who, as a consequence, also feel more secure, relaxed and collaborative.

Integration is understood as the efforts used in maintaining the activities and relationships among the varying members in a cohesive way, respecting each one's autonomy, while recognizing their interdependence. ${ }^{11}$ Collaboration covers each professional's contribution to the health care, and for this requires the recognition of zones of influence in the roles performed. These zones allow one to emphasize the competences, which are not prerogatives of each discipline, but, rather, are guided and directed to a common objective regarding the subjects' health care. Collaboration is supported by the recognition of each discipline's equality, and, at the same time, in the parity, that is, in the respect for the differences. ${ }^{11}$

Still in relation to integration, nurses commonly share space with students from various disciplines, with whom they must maintain cooperative relationships. Education, through refresher courses and continuous education, contributes to the members of the nursing team being able to progress in their careers, improve their knowledge, and, consequently, improve their skills and competences in the nursing activities and in the care for patients and their family members. The importance of the nurse acting as a being of care, encouraging and supporting the initiatives for improvement on the part of the team, has already been noted.

The encouragement to undertake research, as well as facilitating professionals' and students' undertaking of studies, is part of a collaborative attitude, opening spaces and cooperating in what is possible to achieve, as long as the institution's regulations and ethical principles are respected. Cooperating, encouraging and undertaking studies in the area of nursing contributes to developing an enriching a body of knowledge, as well as es- 
tablishing interrelationships between theory and practice, allying art and science.

In the figure, the dimensions, represented by the interconnecting circles, in which the caring relationships and the caring environment occur, motivated and created through nursing in a cultural organization of health, are reflected and reach out to a wider environment, with the community and - later - spread out around the planet, when this ideal is spread and practiced among the beings who live in our ecosystem.

The nurse, as a caring being and exerciser of leadership, is the subject who reflects the behaviors and attitudes of care serving as a model, represented in the figure as spiral tubes.

In short, collaborative care, for the author of the present work, is understood as a work of leadership of the nurse, in which people (professionals of the nursing team and other professionals from the health area) are encouraged to share experiences and knowledge, to respect each one's space, and to contribute to the development and improvement of the quality of the care for the patient and her family members.

\section{FINAL CONSIDERATIONS}

The environment is presented as a factor which is always present; that is, there is a constant interaction between the subjects and their surroundings. As a result, the external environment exercises an influence on the subject in her interiority, her physical and organic structure, and in how she relates with the beings, with life, and with her wider surroundings.

It is important to emphasize that the nurse whose center of interest is the care for the subject, and who believes in caring as the essence of nursing, simply needs to put her knowledges, intuition, beliefs, values and ethical principles into action; furthermore, she needs to awaken her care consciousness, actioning the reflexive process or critical thinking, analyzing the situation and planning and undertaking actions which are centered on clear objectives. The rational attitude, accompanied by sensitivity, brings together the art and science of nursing, allowing humane and responsible care. There is no need for elaborating diagnoses but, rather, for action, through the clear formulation of objectives with the planning of care directed to the subject, undertaken for him, with him and his family; and individualized care, adapted to the needs of the same, of his characteris- tics, considering his current experience. In order to optimize the care, the collaboration in conjunction with the other members of the health team, sharing knowledges, responsibilities, exchanging information and proposing, suggesting and modifying actions will result in a true teamwork.

Collaborative care allows nursing and the professionals to be able to work in a climate of camaraderie, partnership and mutual help, allowing the better facing of situations, nowadays fairly common in the health institutions, such as conflicts, ethical dilemmas, the seriousness and multiplicity of illnesses, and the fragility of resources, as well as the complexity in the performance of skills and competences in the light of constant changes and the increasingly present high technology. The professionals need to constantly be updating their knowledge, as the market has become significantly competitive, and the situations listed are a source of stress - another reason for collaborative work.

The leadership style is decisive for the success of the work, and I believe that the participative form mentioned as transformative facilitates the development of relationships with the various departments, establishing negotiations which satisfy everybody. The team's support helps such that the leader feels more secure in the sense of disseminating knowledge and arguing in favor of the group, emphasizing the relevance of the care. This is because, as a rule, the organizations gravitate around principles such as bureaucracy, rationality, specialization, economising, impersonality, and the establishment of rules and policies. These, in general, differ from the principles of nursing, focused on the subject cared for and on what caregivers need in order to develop and provide high quality care. Making the nurses' work more arduous, the health organizations privilege the doctors' needs, reinforcing a policy of power. As a result, the nurses and the leader of the group need to use shrewdness, patience and knowledge. As mentioned above, they must be trained and confident in their role, transmitting this with confidence. Collaborative care, as one of the goals, will result - in addition to the various benefits already mentioned - in greater respect, recognition and adherence of the professionals of the multi-professional team and of management for a policy of care and for success in the planned and shared actions.

Concluding, this work intended as its objective to share a proposal of a vision regarding collaborative care. I consider the role of the man- 
ager in nursing (understanding that all nurses, regardless of their position, exercise the role of manager) as fundamental for promoting collaborative work, and that this only occurs to the degree that one values and recognizes the care as essential, demonstrating behaviors and attitudes which are compatible with the principles of care, favoring the creation of relationships of care and of an environment of care.

\section{REFERENCES}

1. Waldow VR. O cuidado na saúde: as relações entre o eu, o outro e o cosmos. Petrópolis (RJ): Vozes; 2004.

2. Waldow VR. Cuidar: expressão humanizadora da enfermagem. Petrópolis (RJ): Vozes; 2006.

3. Waldow VR. Bases e princípios do conhecimento e da arte da enfermagem. Petrópolis (RJ): Vozes; 2008.

4. Waldow VR. Uma experiência vivida por uma cuidadora, como paciente, utilizando a narrativa literária. Texto Contexto Enferm. 2011 Out-Dez; 20(4):825-33.
5. Wolff L, Waldow VR.Violência consentida: mulheres em trabalho de parto e parto. Saúde Sociedade. 2008; 17(3):138-51.

6. Portella RJ, Pereira RL, Demutti PF, Rutz PA, Buss TM. Implicações do ambiente no desenvolvimento do processo de trabalho da enfermagem: uma revisão integrativa. Enferm Glob [online]. 2012; 11(27):37987 [acesso 2014 Jan 01]. Disponível em http:/ / scielo. isciii.es/pdf/eg/v11n27/pt_revision3.pdf

7. Johns C, Freshwater D. Transforming nursing through reflective practice. Massachussetts (US): Blackwell Science; 1998.

8. Schön DA. The reflective practitioner: how professionals think in action. New York (NY): Basic Books; 1983.

9. Schön DA. Educando o profissional reflexivo: um novo design para o ensino e a aprendizagem. Porto Alegre (RS): ARTMED; 2000.

10. Waldow VR. Momento de cuidar: momento de reflexão na ação. Rev Bras Enferm. 2009; 62(1):140-5.

11. Kérouac S, Pepin J, Ducharme F, Duquette A, Major F. El pensamiento enfermero. Barcelona (ES): Elsevier/Masson; 1996. 